\title{
Development of an Automated Stand for Measuring the Thermal Characteristics of Solar Parabolic Trough Collectors
}

\author{
Yodgor Akbarovich Yusupov ${ }^{1}$, Oybek Hamdamovich Otaqulov ${ }^{2}$, Sirojiddin Fayozovich Ergashev ${ }^{2}$, \\ Akmal Ahmadaliyevich Kuchkarov ${ }^{2, *}$ \\ ${ }^{1}$ Natural Disciplines, Computer Engineering, Fergana Branch of Tashkent University of Information Technologies, Fergana, Uzbekistan \\ ${ }^{2}$ Intelligent Engineering Systems, Energy, Fergana Polytechnic Institute, Fergana, Uzbekistan
}

\author{
Email address: \\ ims-79@mail.ru (A. A. Kuchkarov) \\ ${ }^{*}$ Corresponding author
}

\section{To cite this article:}

Yodgor Akbarovich Yusupov, Oybek Hamdamovich Otaqulov, Sirojiddin Fayozovich Ergashev, Akmal Ahmadaliyevich Kuchkarov. Development of an Automated Stand for Measuring the Thermal Characteristics of Solar Parabolic Trough Collectors. International Journal of Sustainable and Green Energy. Vol. 10, No. 1, 2021, pp. 28-31. doi: 10.11648/j.ijrse.20211001.15

Received: March 4, 2021; Accepted: March 19, 2021; Published: March 30, 2021

\begin{abstract}
In the manufacture, assembly, testing and operation of solar power plants, one has to deal with a wide variety of control and measuring operations, as well as means of control and measurement of physical quantities. Analysis of methods and means of control of solar parabolic trough installations showed that they are numerous and time consuming. This requires the development of modern automated systems for measuring, recording and processing the results of the energy characteristics of solar installations. This article describes an automated stand for measuring the thermal and energy characteristics of solar parabolic trough collectors. The developed experimental setup consists of a parabolic trough collector, a measuring tank, a converter, a meter, a level gauge, temperature sensors and electric valves. Consumption (energy generated) is measured with a graduated water tank. By measuring the volume of water and the temperature passed through the solar collector, you can estimate its efficiency. Several portions of heated water are collected in the measuring tank, depending on the intensity of the heating process. As the graduated tank fills, the digital output level gauge opens the electrical drain valve. On the basis of statistical processing of experimental data, the energy characteristics of the solar parabolic trough installation are determined.
\end{abstract}

Keywords: Parabolic Trough Collector, Concentration, Aperture, Receiver, Converter, Sensor

\section{Introduction}

In the past two decades, concentrated solar energy technologies have received more and more attention to replace traditional energy technologies and reduce their environmental impact. Solar energy is an affordable and clean form of renewable energy used as an alternative to fossil fuels in energy production. However, the maximum extraction of thermal energy from the Sun is the most difficult task [1].

To meet this challenge, various manifolds have been modeled, designed, manufactured and tested to operate in various temperature ranges such as low temperature, medium temperature and high temperature manifolds. In applications such as process heat supply and steam generation, the parabolic trough solar collector (PTC) is considered the most popular among other collectors $[2,3,4,5]$. Numerous studies, both theoretical and experimental, have been carried out over almost three decades to improve the optical and thermal efficiency of the system. Optical efficiency depends on material properties such as the reflectance of the mirror, the transmittance of the glass coating, the absorption coefficient, the emissivity of the receiver, the intercept, the geometric coefficient, and the angle of incidence. Thermal efficiency depends on the total loss factor, which includes losses due to conduction, convection and radiation $[6,7]$.

The rate of the local concentration coefficient on the receiver tube and the optical efficiency are determined by two 
main characteristics of the geometric optimization of the PTC [8].

The flow density at the absorber wall is non-uniform and complex, and the calculation of the flow distribution is key for evaluating the optical characteristics of the PTC and analyzing the characteristics of the flow of liquids in a tubular absorber [9]. Also, the geometric shape and position of the receiver affects the optical efficiency and heat flux distribution [10].

In the manufacture, assembly, testing and operation of solar power plants, one has to deal with a wide variety of control and measurement operations, as well as means of control and measurement of physical quantities. At the same time, for the high-quality performance of these operations, it is necessary to apply scientifically based methods of control and measurement. Analysis of methods and means of control of solar parabolic trough installations showed that they are numerous and time consuming. This requires the development of modern automated systems for measuring, recording and processing the results of the energy characteristics of solar installations.

\section{Methods and Materials}

The development of modern solar installations requires constant improvement of methods and means for determining their characteristics, i.e. use of solar simulators, high-precision spectroradiometric equipment and measuring systems with analog, digital and computer processing of results.

The use of the element base of modern optoelectronics and microelectronics makes it possible to create more compact and high-precision optoelectronic devices for measuring the energy characteristics of solar installations. With the development of digital and processor control means of a computerized system of measurements, registration and processing of results, it makes it possible to automate the process of measuring and registering the energy characteristics of solar systems [11, 12, 13].

The developed experimental setup consists of a PTC, a measuring tank, a converter, a meter, a level gauge, temperature sensors and electric valves. Consumption (energy generated) is measured with a graduated water tank. By measuring the volume of water and the temperature passed through the solar collector, you can estimate its efficiency. Several portions of heated water are collected in the measuring tank, depending on the intensity of the heating process. As the graduated tank fills, the digital output level gauge opens the electrical drain valve. On the basis of statistical processing of experimental data, the energy characteristics of the solar parabolic trough installation are determined.

The test rig is at the correct level. All experimental data in archive format are stored in real time on a computer. For this SCADA system TraceMode is installed and launched on the computer. The measured information from the TPM 138 meter through the RS-485 interface is fed to the I-7020 converter. After conversion to RS-232 through the Comport it is received into the computer. A special program for processing experimental data has been developed in the TraceMode environment.

\section{Results and Discussion}

We have investigated the optical and thermal characteristics of the energy module of a solar parabolic trough installation with geometric characteristics: $B \times L=2000 \times 5000 \mathrm{~mm}$, focal length $f=866 \mathrm{~mm}$ and angle of coverage $\alpha=60^{\circ}$. The reflective surface is formed by sheets of mirror-like aluminum made in Germany with integral reflection of sunlight $R_{\mathrm{z}}=0,79 \div 0,80$. The PTC was installed at the test site of the Fergana Polytechnic Institute in the west-east direction.

The collector is mounted on two welded trusses, ensuring its installation at a specific calculated angle for the latitude of the area relative to the horizon. In the focal plane of the collector, a receiver of a calculated dimension in the form of a tube is installed on adjustable fasteners. The receiver is a stainless steel pipe with an outer diameter $d_{\mathrm{T}}=32 \mathrm{~mm}$, the length of the evaporative heat pipe is $l_{\mathrm{p}}=5000 \mathrm{~mm}$. The heat carrier is water.

The vertical axis of the unit allows you to orient the unit towards the zenith. The orientation of the installation to the Sun is carried out manually. This energy module consists of a parabolic trough collector and an insulated measuring tank with a capacity of 50 liters (Figure 1).

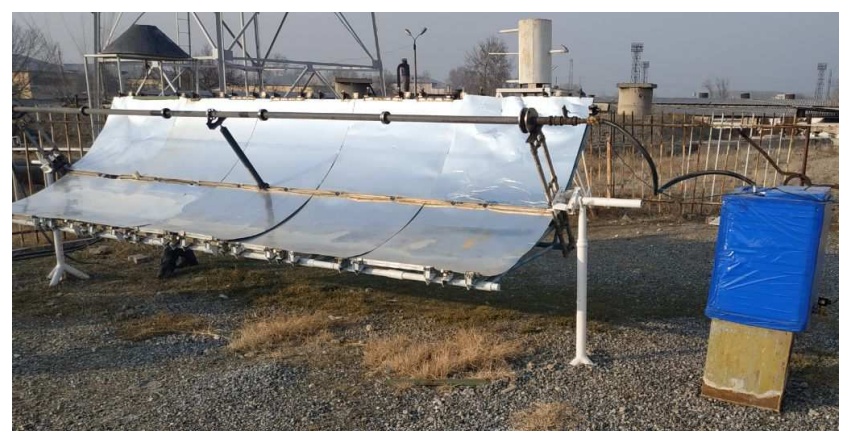

Figure 1. General view of the PTC.

To measure the thermal characteristics of the solar parabolic trough module, in contrast to the traditional ones [14], we have developed remote measuring systems and special programs for data processing [15], where the possibility of a comprehensive analysis of the optical-energy characteristics of the PTC is provided. For this purpose, a software and hardware complex has been developed to determine the thermal indicators of the system as a whole.

The essence of the method is to register and process the results of the energy characteristics of a solar parabolic trough installation, at the same time to show the efficiency and practical feasibility of using this module, since it ensures the accuracy and efficiency of measurements with minimal error.

The developed experimental setup is shown schematically in Figure 2. It contains all the equipment used and the connection sequence. 


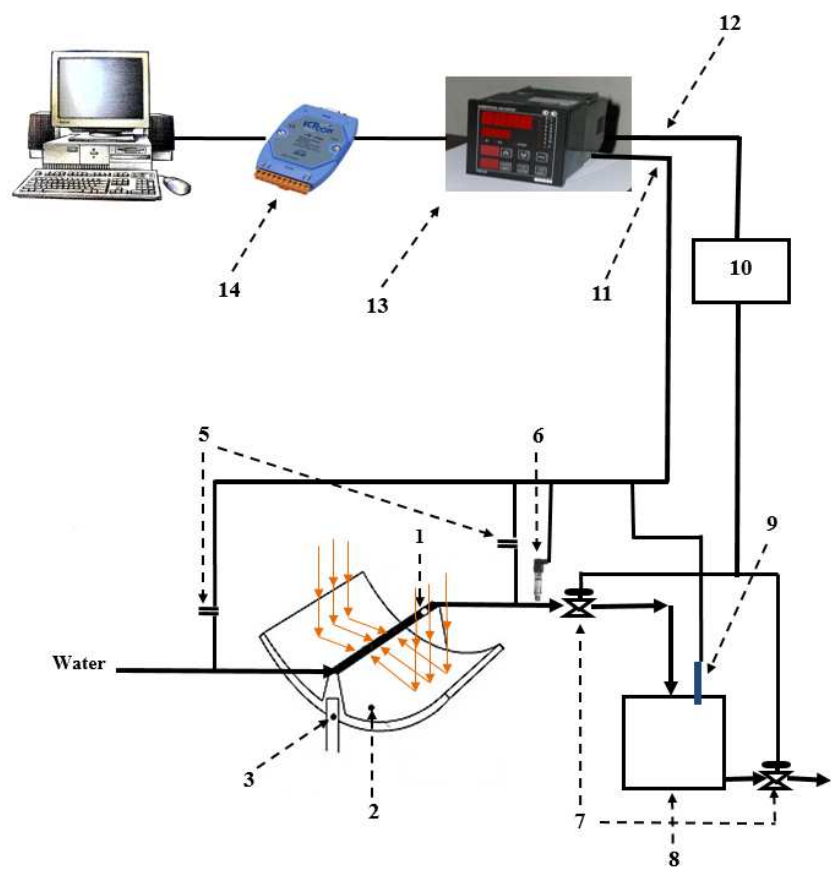

Figure 2. Diagram of an automated stand for measuring, recording and processing the results of the energy characteristics of solar parabolic trough installations (1-receiver, 2-concentrator, 3-follower, 4-check valve, 5-temperature sensor, 6-pressure sensor, 7 electric valve, 8-measuring tank, 9-level gauge, 10-relay unit, 11-input signals, 12-output signals, 13-meter regulator, 14-converter).

In the stand, the main measuring instruments are an 8-channel microprocessor-based meter - TPM 138 regulator. Three temperature sensors are connected to it, one of them is a pressure sensor and the second level sensor with a discrete output. Consumption (energy generated) is measured with a graduated tank. By measuring the volume of the heat carrier (water) and the temperature passed through the solar collector, you can estimate its efficiency.

The algorithm for testing solar collectors is based on partial accumulation at set temperatures. The temperature of heating the heat carrier (water) can be set up to $100^{\circ} \mathrm{C}$ and higher, based on the need. The heat carrier (water) is supplied to the solar collector under a pressure of $2 \mathrm{~kg} . \mathrm{s} / \mathrm{cm}^{2}$. The electric valve is closed, the temperature in the manifold is measured. For example, when the temperature of the heat carrier (water) reaches $60^{\circ} \mathrm{C}$, the valve automatically opens and the heated heat carrier (water) is poured into the measuring tank. The time of the open state of the electric valve is determined experimentally and is set on the meter-controller as the temperature setting. In the measuring tank, several portions of the heated heat carrier (water) are collected, depending on the intensity of the heating process. As the graduated tank fills, the digital output level gauge opens the electrical drain valve. On the basis of statistical processing of experimental data, the thermal characteristics of the solar parabolic trough installation are determined.

The test rig is at the correct level. All experimental data in archive format are stored in real time on a computer. For this SCADA system TraceMode is installed and launched on the computer. The measured information from the TPM 138 meter through the RS-485 interface is fed to the I-7020 converter. After conversion to RS-232 through the Comport it is received into the computer. A special program for processing experimental data has been developed in the TraceMode environment. The processing results are shown in Figure 3.

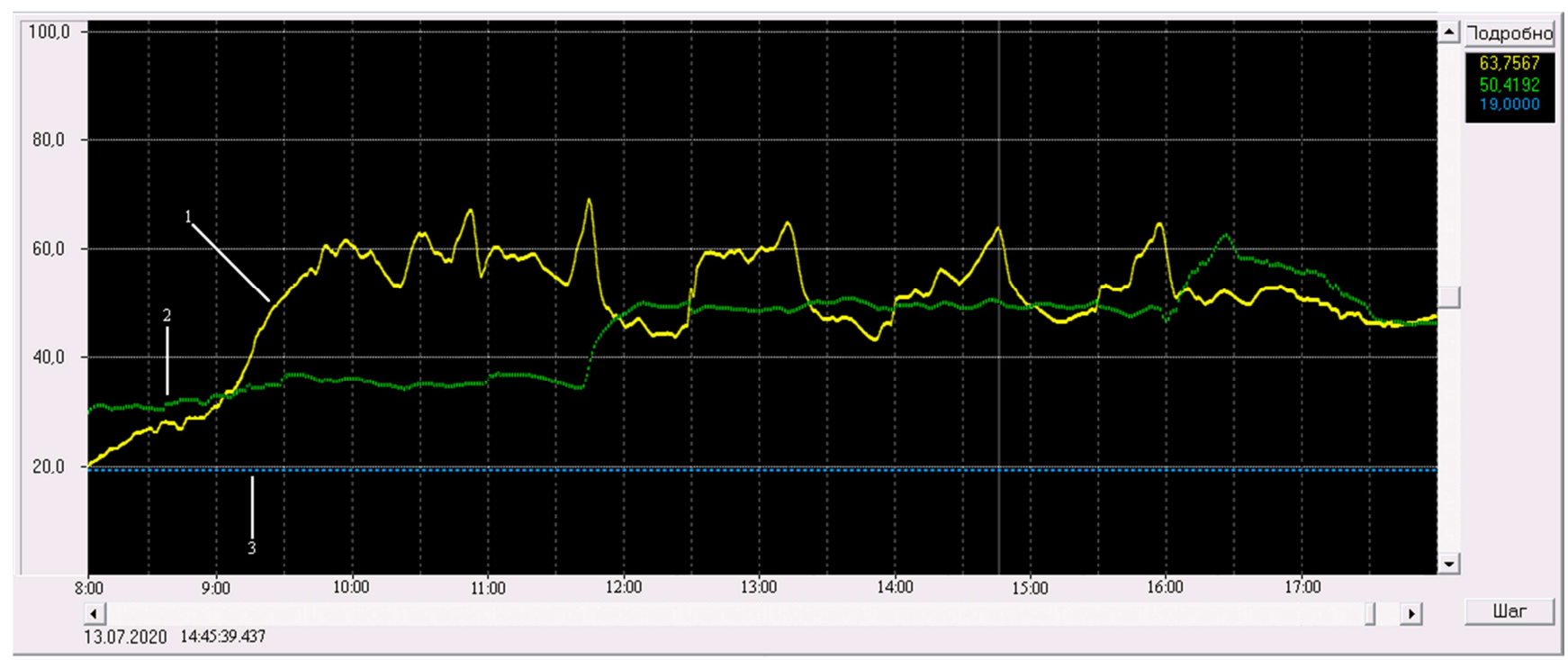

Figure 3. Heat carrier (water) temperature measurement trends.

The jumps of line (1) in Figure 3 means the discharge of the coolant (water) that has reached a temperature of $60^{\circ} \mathrm{C}$ into the measuring tank, line (2) means the temperature of the coolant (water) in the measuring tank, line (3) the temperature of the coolant (water) entering the receiver.
Thus, the developed automated stand for measuring the thermal and energy characteristics of solar PTC makes it possible to automate data collection and processing of the results of thermal parameters of PTC, which will lead to simplification and accuracy of the results. 


\section{Conclusion}

An automated stand has been developed for measuring the thermal and energy characteristics of solar parabolic trough collectors. The stand consisting of a parabolic trough collector a measuring tank, a converter, a meter, a level gauge, temperature sensors and electric valves, measuring the volume of water and the temperature passed through the solar collector, makes it possible to evaluate the efficiency of the collector. The test algorithm is based on partial accumulation at set temperatures. Several portions of heated water are collected in the measuring tank, depending on the setting of the desired temperature. As the measuring tank is filled, the discrete output level gauge opens the electrical drain valve and the heated water is automatically transferred to the consumer. All operations and measurements are carried out automatically in real time.

A method for automated measurement, registration and processing of thermal indicators of parabolic trough collectors has been developed. On the basis of statistical processing of experimental data, the energy characteristics of the solar parabolic trough installation are determined.

The results of using the developed automated stand for measuring, recording and processing the results of the energy characteristics of the solar parabolic trough installation showed the operability and practical feasibility of using this stand, since it ensures the accuracy and efficiency of measurements with a minimum error.

In general, the proposed stand, based on the simplicity of design, accuracy, efficiency, and technical capabilities, meets the requirements of researchers and allows automating the process of measuring and recording the energy characteristics of solar systems.

\section{Acknowledgements}

The work was carried out within the framework of the state program of the Ministry of Innovative Development of the Republic of Uzbekistan under the project of fundamental research T-F-3-19 of the Fergana Polytechnic Institute.

\section{References}

[1] K. Lovegrove, and W. Stein, Concentrating Solar Power Technology. Principles, Developments and Applications, 1st ed., Vol. 21 of Woodhead Publishing Series in Energy, Cambridge: Woodhead, 2012.

[2] Amir Shahsavari, Morteza Akbari. Potential of solar energy in developing countries for reducing energy-related emissions // Renewable and Sustainable Energy Reviews Volume 90, July 2018, Pages 275-291. https://doi.org/10.1016/j.rser.2018.03.065
[3] L. Valenzuela, et al. Optical and thermal performance of large-size parabolic-trough solar collectors from outdoor experiments: A test method and a case study / Energy 70 (2014) 456-464. https://doi.org/10.1016/j.energy.2014.04.016

[4] G. K. Manikandanetal, Enhancing the optical and thermal efficiency of a parabolic trough collector-A review // Applied Energy $235 \quad$ (2019) 1524-1540. https://doi.org/10.1016/j.apenergy.2018.11.048

[5] Hamzeh Jamali. Investigation and review of mirrors reflectance in parabolic trough solar collectors (PTSCs) /Energy Reports 5 (2019) 145-158. https://doi.org/10.1016/j.egyr. 2019.01.006

[6] A. A. Abdurakhmanov, A. A. Kuchkarov, M. A. Mamatkosimov, et al. The optimization of the optical-geometric characteristics of mirror concentrating systems. Appl. Sol. Energy 50, 244-251 (2014). https://doi.org/10.3103/S0003701X14040033

[7] Z. Zhao, et al. Experimental study of pin finned receiver tubes for a parabolic trough solar air collector // Solar Energy 207 (2020) 91-102. https://doi.org/10.1016/j.solener.2020.06.070

[8] R. A. Zakhidov, Sh. I. Klychev, Maximum concentrating power of parabolic trough mirrors, Appl. Solar Energy, 1993, vol. 29, no. 4 , pp. $56-58$.

[9] M. M. Muhitdinov, S. F. Ergashev, Solnechnye parabolotsilindricheskie ustanovki, Tashkent: Fan. 1995, 208 p.

[10] A. Kuchkarov, et al. Calculation of Thermal and Exergy Efficiency of Solar Power Units with Linear Radiation Concentrators // Applied Solar Energy, 2020, Vol. 56, No. 1, pp. 42-46. DOI: 10.3103/S0003701X20010089.

[11] REN21. Renewable Energy Policy Network. 2005. "Renewables 2005 Global Status Report/'Washington, DC: Worldwatch 1. stitute. www.ren21.net.

[12] O. S. Popel, Effektivnost primeneniya solnechnih vodonagrevateley $\mathrm{v}$ klimaticheskih usloviyah sredney polosi Rossii // Energosberejenie №1. 2001.

[13] V. I. Vissarionov, S. V. Belkina, G. V. Deryugina, V. A. Kuznetsova, N. K. Malinin, Energeticheskoye oborudovaniye dlya ispolzovaniya netraditsionnih $\mathrm{i}$ vozobnavlyayemih istochnikov energii. Spravochnik. Pod red. V. I. Vissarionova. M. 2004. 448p.

[14] A. A. Kuchkarov, Lineino-kontsentriruyushie sistemy solnechnogo izlucheniya (Solnechnye kontsentratory energeticheskogo naznacheniya), Palmarium Academic Publishing, 2019. https://www.amazon.com/Lineino-kontsentriruyushchie-sistemy-so lnechnogo-izlucheniya-energeticheskogo/dp/6202383577.

[15] S. F. Ergashev, O. H. Otaqulov, S. M. Abdurahmonov, Yo. A. Yusupov, Avtomatizirovanniy stend dlya izmereniy, registratsii i obrabotki rezultatov energeticheskih harakteristik solnechnih parabolotsilindricheskih ustanovok. Materiali V mejdunarodnoy konferensii "Opticheskie i fotoelektricheskie yavleniya $\mathrm{v}$ poluprovodnikovih mikro- i nanostrukturah", Fergana, 2020, pp. 363-366. 